\title{
- - Nordisk Ministerråds samarbejdsprogram for arbejdsliv 2018-2021
}

(11) Nordisk Ministerråd 


\title{
Nordisk Ministerråds samarbejdsprogram \\ for arbejdsliv 2018-2021
}

\author{
ANP 2018:712 \\ ISBN 978-92-893-5403-5 (PRINT) \\ ISBN 978-92-893-5404-2 (PDF) \\ ISBN 978-92-893-5405-9 (EPUB) \\ http://dx.doi.org/10.6027/ANP2018-712 \\ (c) Nordisk Ministerråd 2018 \\ Layout: Gitte Wejnold \\ Omslagsfoto: Unsplash.com \\ Tryk: Rosendahls \\ Printed in Denmark
}

\section{Det nordiske samarbejde}

Det nordiske samarbejde er en af verdens mest omfattende regionale samarbejdsformer. Samarbejdet omfatter Danmark, Finland, Island, Norge og Sverige samt Færøerne, Grønland og Åland.

Det nordiske samarbejde er både politisk, økonomisk og kulturelt forankret og er en vigtig medspiller i det europæiske og internationale samarbejde. Det nordiske fællesskab arbejder for et stærkt Norden i et stærkt Europa.

Det nordiske samarbejde ønsker at styrke nordiske og regionale interesser og værdier i en global omverden. Fælles værdier landene imellem er med til at styrke Nordens position som en af verdens mest innovative og konkurrencedygtige regioner.

\section{Nordisk Ministerråd}

Nordens Hus

Ved Stranden 18

1061 København K

www.norden.org

Download nordiske publikationer: www.norden.org/nordpub 


\section{Nordisk Ministerråds samarbejdsprogram for arbejdsliv 2018-2021}




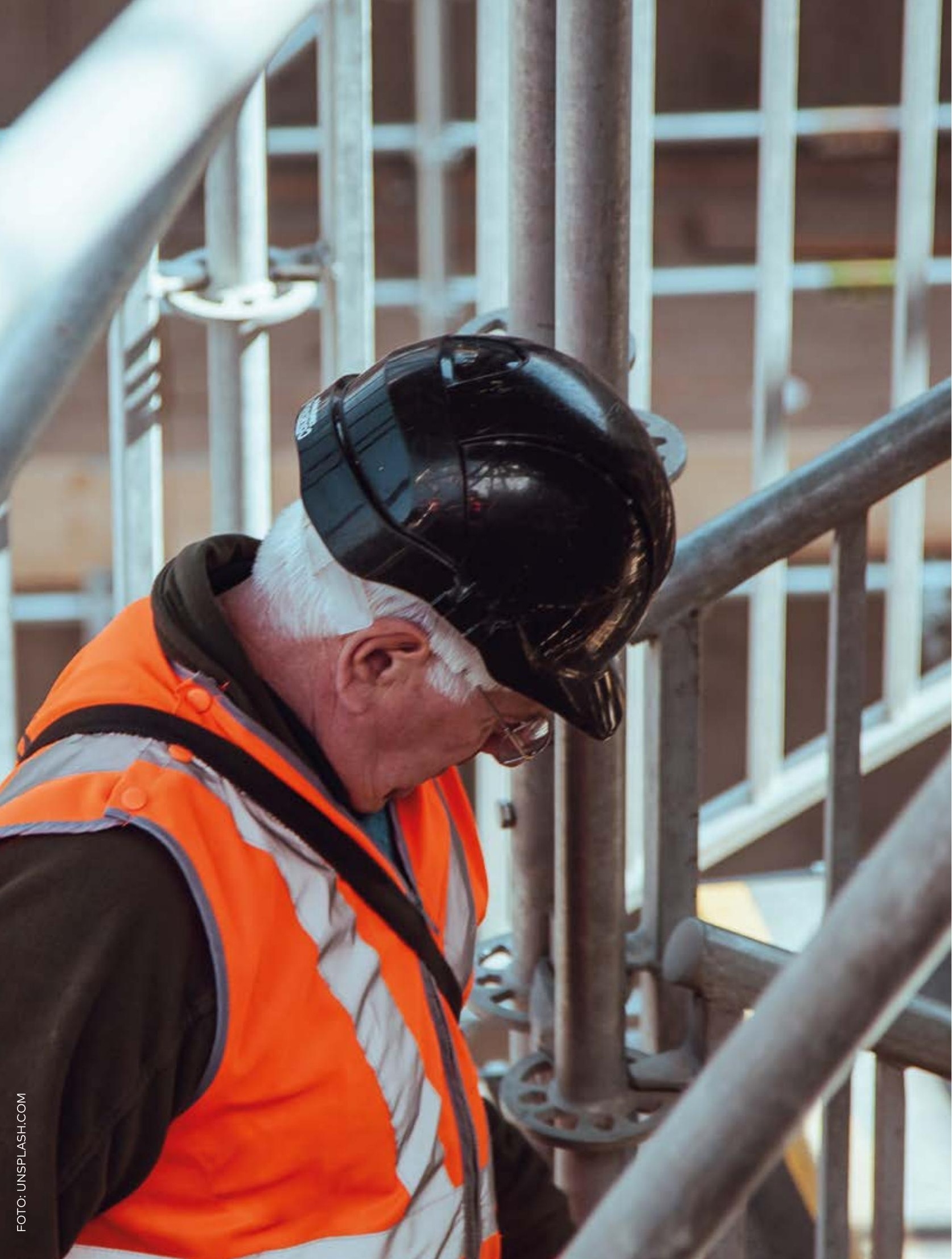




\section{Indhold}

Om Nordisk Ministerråds samarbejdsprogram 6

Om samarbejdsprogrammet for arbejdsliv

Strategiske indsatsområder 8

Indsatsområde 1

Indsatsområde 2

Indsatsområde $3 \quad 12$

Indsatsområde 4 14

Samarbejde om EU og andre internationale aktører 17

$\begin{array}{ll}\text { Organisation på området } & 18\end{array}$

Arbejdslivsområdets institution for videreuddannelse inden for arbejdsmiljøområdet - NIVA 20

Gennemførelse af samarbejdsprogrammet $\quad 22$ 


\section{Om Nordisk Ministerråds samarbejdsprogram}

Samarbejdsprogrammet for Nordisk Ministerråd for Arbejdsliv (MR-A) beskriver centrale politiske udfordringer og prioriteringer på området i perioden 2018-2021. Formålet med samarbejdsprogrammet er at definere det strategiske fokus for det formelle nordiske regeringssamarbejde. Programmet indeholder en overordnet beskrivelse af de indsatsområder, hvor der kan skabes konkrete initiativer og projekter. Samarbejdet på arbejdslivsområdet inkluderer de nordiske lande samt Færøerne, Grønland og Åland og omfatter beskæftigelses- og arbejdsmarkedsområdet samt arbejdsmiljø- og arbejdsretsområdet.

Samarbejdsprogrammet har en styrende funktion på området og skal betragtes i relation til andre styringsdokumenter inden for det nordiske samarbejde. Samarbejdsprogrammet understøtter både de nordiske statsministres udtalelse fra 2016 om at gøre Norden til verdens mest integrerede region og de nordiske samarbejdsministres vision Sammen er vi stærkere, som blev vedtaget i 2014. Nordisk Ministerråds tværgående strategier - ligestilling, bæredygtig udvikling, børn og unge, integration og funktionshindringer - vil også blive integreret i programmet.
| 2016 foretog den tidligere danske minister og EU-kommissær Poul Nielson på opdrag af MR-A en strategisk analyse af arbejdslivsområdet. Analysen resulterede i rapporten Arbejdsliv i Norden - udfordringer og forslag, som blev taget op på MR-A's møde i november 2016. Rapportens temaer, analyser og forslag samt MR-A's konklusioner fra mødet udgør samlet set et vigtigt grundlag for dette samarbejdsprogram.

Samarbejdet på arbejdslivsområdet handler i høj grad om at udrede, analysere og diskutere ligheder og forskelle mellem de nordiske lande, hvad angår tiltag, resultater og bedste praksis i forhold til fælles udfordringer. Samarbejdet kan bidrage med inspiration til de enkelte landes udvikling af politikker på nationalt plan, men også give mulighed for, at man, i de tilfælde, hvor det forekommer at være relevant og kan generere nordisk nytte, kan koordinere sine synspunkter på områder, hvor landene kan opnå mere i fællesskab end hver for sig. 


\section{OM SAMARBEJDSPROGRAMMET FOR ARBEJDSLIV}

Arbejdslivet spiller en afgørende rolle for udviklingen af de nordiske velfærdssamfund, for erhvervslivet og for det enkelte individ. Det fælles arbejdsmarked er en af hjørnestenene i det nordiske samarbejde. En stor og kompetent arbejdsstyrke er vores vigtigste ressource, og den danner grundlaget for et konkurrencedygtigt nordisk arbejdsmarked og for udviklingen af de nordiske velfærdssamfund. Norden udmærker sig i international sammenhæng ved, at både mænd og kvinder har et højt uddannelsesniveau.

De nordiske arbejdsmarkeder står dog over for betydelige forandringer som følge af blandt andet den demografiske udvikling, øget globalisering og international konkurrence. Teknologiens hastige udvikling har konsekvenser for efterspørgsel, kompetencekrav, organisering og indhold i arbejdslivet. Udviklingen medfører en række nye muligheder, men kan også føre væsentlige udfordringer med sig.

Samarbejdsprogrammet for arbejdsliv 2018-2021 peger på en række væsentlige udfordringer på arbejdslivsområdet og beskriver, hvordan det nordiske samarbejde kan bidrage til at løse dem. Samarbejdsprogrammet formulerer en række vigtige præmisser for det nordiske samarbejde på arbejdslivsområdet. I programmet defineres temaer og problemstillinger, som vil få en central rolle i diskussioner og erfaringsudveksling mellem de nordiske lande og kommer til at ligge til grund for indsamling af viden og eksempler på bedste praksis i fireårsperioden.

Regeringerne i samtlige nordiske lande arbejder løbende på at bidrage til et velfungerende arbejdsliv samt til bæredygtig vækst og beskæftigelse. Gennem det nordiske samarbejde modtager regeringerne nyttig information og inspiration til dette arbejde.

I programperioden vil samarbejdet på arbejdslivsområdet hovedsageligt fokusere på følgende indsatsområder:

- Styrke matchingen mellem udbuddet af og efterspørgslen efter kompetent arbejdskraft samt øge arbejdsmarkedsdeltagelsen, især blandt udsatte grupper.

- Styrke et godt arbejdsmiljø for både kvinder og mænd, blandt andet ved at forebygge arbejdsrelaterede sygdomme og skader samt afskaffe uacceptable arbejdsforhold.

- Sikre en god balance mellem arbejdstagerbeskyttelse og fleksibilitet samt værne om den nordiske trepartsbaserede arbejdsmarkedsmodel.

- Styrke integration, lige muligheder og mobilitet på det nordiske arbejdsmarked.

Samarbejdsprogrammet blev vedtaget den 28. november 2017, træder i kraft den 1. januar 2018 og gælder indtil udgangen af 2021. 


\section{Strategiske indsatsområder}

Samarbejdet på arbejdslivsområdet vil i den aktuelle periode primært fokusere på en række mål, som skal imødegå de langsigtede udfordringer og muligheder, som det nordiske arbejdsmarked står over for. Nogle af de udfordringer, som det fremtidige nordiske arbejdsliv står over for, udspringer af internationaliseringen af arbejdsmarkedet, digitaliseringen og deleøkonomiens indtog samt deres indvirkning på ansættelsesformer, organisationsgrad og arbejdsmiljø.

Automatisering og robotificering kan medføre, at arbejdspladser forsvinder eller forandres. Udfordringer i form af voksende skel, lavtlønskonkurrence og marginalisering samt adgang til kompetencer og videreuddannelse gennem hele arbejdslivet er centrale. Behovet for at inkludere udsatte grupper på arbejdsmarkedet er fortsat aktuelt, og migrationen til Europa samt det øgede antal nyankomne øger desuden behovet for en forbedret integration. En varierende grad af arbejdsmarkedsdeltagelse og beskæftigelse blandt indvandrere er en udfordring for de nordiske lande. Den aldrende befolkning bliver længere på arbejdsmarkedet, men det indebærer også en udfordring i forhold til at sikre et tilstrækkeligt udbud af arbejdskraft og imødegå et stigende behov for velfærds- ydelser i de nordiske lande. Det gælder især de steder i Norden, hvor antallet af personer i den arbejdsduelige alder er faldende.

Det nordiske samarbejde vil fokusere på langsigtede udfordringer. Samarbejdet vil dog også tillade en vis fleksibilitet, så man ved behov kan fokusere på konjunkturafhængige udfordringer og uforudsigelige hændelser, der eventuelt måtte indtræffe i programperioden.

De udfordringer og udviklingstendenser, som vi har i vente, er på mange måder sammenknyttede og derfor svære at adskille klart fra hinanden. Alt i alt er der belæg for at sige, at de nordiske arbejdsmarkeder står over for en situation, som kan få stor betydning for fremtidens arbejdsliv og samfund. Derfor kan det potentielt være værdifuldt at tilnærme sig disse udfordringer gennem det nordiske samarbejde. Opfølgning og samarbejde om bredere og mere integrerede udredninger, statistik og aktuelle fremtidsanalyser kan fungere som bidrag til dette arbejde sammen med løbende erfaringsudveksling, faglige og politiske drøftelser samt gensidig læring mellem de nordiske lande. 


\section{INDSATSOMRÅDE 1}

Styrke matchingen mellem udbuddet af og efterspørgslen efter kompetent arbejdskraft samt øge arbejdsmarkedsdeltagelsen, især blandt udsatte grupper.

En af de primære prioriteringer for samarbejdet på beskæftigelses-og arbejdsmarkedsområdet er at bidrage til at opnå den højest mulige arbejdsmarkedsdeltagelse blandt kvinder og mænd samt det lavest mulige antal personer, der permanent står uden for arbejdsmarkedet.

Nogle af de vigtige mål på beskæftigelses- og arbejdsmarkedsområdet er blandt andet at:

\section{Øge arbejdsmarkedsdeltagelsen, især blandt udsatte grupper på arbejds-} markedet. Det indebærer et fokus på en hurtigere og mere effektiv integration af blandt andet unge, langtidsledige, ældre og indvandrere på arbejdsmarkedet.

Videre lægges der vægt på at mindske sygefraværet blandt arbejdstagere og øge arbejdsdeltagelsen blandt personer med nedsat arbejdsevne og funktionshindringer. Udviklingen i psykiske sundhedsproblemer, især blandt unge, er bekymrende og kræver opmærksomhed. Det er vigtigt at sikre, at de personer, der kommer i arbejde, magter at beholde deres arbejde, og at ældre arbejdstagere bliver på arbejdsmarkedet så længe som muligt. Arbejdsmarkedsdeltagelsen skal desuden øges i den forstand, at de personer, der arbejder på deltid og ønsker at øge deres deltagelse på arbejdsmarkedet, får mulighed for at arbejde mere. Inddragelse af og samarbejde med forskellige berørte aktører på arbejdsmarkedet er vigtigt for at indfri målet om øget arbejdsmarkedsdeltagelse.

\section{Opnå en bedre overensstemmelse} mellem udbud af og efterspørgsel efter arbejdskraft. Der vil blive fokuseret på hvordan man kan styrke matchingen på arbejdsmarkedet med henblik på at reducere flaskehalse og sikre en bedre udnyttelse af ressourcerne på arbejdslivsområdet. Et godt match mellem dem, der søger arbejde, og dem, der søger arbejdskraft, forudsætter, at arbejdsformidlere kender arbejdsmarkedets behov og har kontakt til både arbejdstagere og arbejdsgivere. Godkendelse af kvalifikationer og relevante kompetencer er fortsat et aktuelt tema, og det samme gælder kravene om faglig og geografisk mobilitet samt forventninger til aktivitet og deltagelse fra den enkelte.

Der vil blive fokuseret på at bekæmpe arbejdsløshed, styrke mulighederne for 




beskæftigelse og modvirke langvarig arbejdsløshed. Unge, indvandrere og personer med lave formelle kompetencer er eksempler på samfundsgrupper med en særligt høj arbejdsløshedsrisiko.

Personer med funktionshindringer som medfører nedsat arbejdsevne, står i højere grad uden for arbejdslivet, selvom de ønsker at komme i arbejde. Der sættes fokus på funktionshindringer, som gør det svært for disse grupper at deltage i arbejdslivet, og på tiltag, som er effektive og bidrager til at få flere i arbejde. I denne sammenhæng er det også vigtigt at fokusere på, hvordan man kan reducere barrierer og styrke mulighederne på arbejdsmarkedet, hvordan man skaber incitament til at arbejde, og hvordan man finder en god balance mellem arbejde, indkomst og velfærdsydelser i de nordiske lande.

\section{Fremme udviklingen af kompetencer, som er tilpasset arbejdsmarkedets}

behov. Der vil være fokus på, hvordan man bedst udvikler arbejdskraftens kompetencer med henblik på at kunne indfri øgede krav til omstilling og sikre, at arbejdsstyrken løbende besidder de kvalifikationer, som arbejdsmarkedet har brug for. Behovet for kompetenceudvikling er særligt aktuelt for personer med lave formelle kvalifikationer og svage grundlæggende færdigheder samt for 
personer med kompetencer, der ikke stemmer overens med arbejdsmarkedets behov. Disse grupper er også mere sårbare over for forandringer og omstillinger $\mathrm{i}$ arbejdslivet, blandt andet i lyset af den teknologiske udvikling. Uddannelsessystemet spiller også en central rolle i forhold til at skabe et højere grundlæggende uddannelsesniveau og sikre, at især unge gennemfører den nødvendige skolegang. Samtidig vil de fleste voksne skulle tillære sig og opnå nye kompetencer livet igennem, så de kan holde sig relevante for arbejdsmarkedet - vanset alder, køn og uddannelsesmæssig baggrund. Det er derfor vigtigt at rette opmærksomheden mod livslang læring, læring i arbejdslivet og på arbejdspladser og muligheden for at videreuddanne sig.

\section{INDSATSOMRÅDE 2}

Styrke et godt arbejdsmiljø for både kvinder og mænd, blandt andet ved at forebygge arbejdsrelaterede sygdomme og skader samt afskaffe uacceptable arbejdsforhold.

Vigtige mål på arbejdsmiljøområdet er at:

Fremme et velfungerende og målrettet arbejdsmiljøarbejde. Den demografiske udvikling og samfundets fremtidige behov for arbejdskraft forudsætter et fokus på virksomhedernes forebyggende arbejde på arbejdsmiljøområdet. Et velfungerende og målrettet arbejde på lokalt niveau med udgangspunkt i de enkelte virksomheders drift og produktion, som muliggør et arbejdsmiljø, hvor arbejdstagerne kan præstere på en produktiv og meningsfuld måde uden risiko for skader og sygdom, er afgørende for, at man kan reducere sygefraværet, forlænge karrieren og øge udsatte gruppers deltagelse i arbejdslivet. Det er vigtigt at fremme børnefamiliers og enkeltpersoners muligheder for at finde arbejde, som muliggør en bedre balance mellem arbejdsliv og privatliv, samt at mobilisere de ældre arbejdstagere, så de bliver længere på arbejdsmarkedet. Der er behov for yderligere viden om, hvilke fremmende og opfølgende indsatser der er brug for på de enkelte arbejdspladser og i de enkelte arbejdsmiljøer for at indfri disse mål. Der er stor forskel på, hvordan virksomheder arbejder med dette, og der er derfor potentiale for forbedringer på området. Det vil være helt centralt at øge forståelsen for arbejdsmiljøets positive indvirkning på produktiviteten, og hvilke indsatser der i særlig grad bidrager til blandt andet at mindske sygefravær og førtidspensionering. 


\section{Styrke et godt fysisk og psykisk arbejds-}

miljø. Der vil være fokus på, hvordan man kan opretholde den enkelte medarbejders ressourcer på et højt niveau og sikre et godt og bæredygtigt arbejdsmiljø for alle gennem hele deres karriere. Opmærksomheden vil især blive rettet mod de store udfordringer, der fremgår af blandt andet sygefraværs- og førtidspensionsstatistikken, hvor muskelog skeletsygdomme samt psykosociale faktorer spiller en central rolle. Derudover vil opmærksomheden blive rettet mod særligt udsatte grupper, for eksempel unge og ældre arbejdstagere, minoritetsgrupper og arbejdstagere med nedsat arbejdsevne samt særligt belastede professioner og sektorer/ brancher. EU's arbejdsmiljøstrategi vil også udgøre et vigtigt fundament for det nordiske samarbejde på dette område.

\section{Afskaffe vacceptable arbejdsforhold og social dumping/arbejdslivskriminalitet.}

Der vil være fokus på, hvordan man kan videreudvikle Norden som et attraktivt arbejdsmarked med høj faglig kompetence og en høj standard for arbejdsvilkår og arbejdsmiljø, som bidrager til at tiltrække den ønskede udenlandske arbejdskraft. Samtidig vil der være udpræget fokus på at forebygge, at $\varnothing$ get arbejdskraftindvandring og lavtlønskonkurrence bidrager til vacceptable arbejdsforhold, løndumping og diskriminering på det nordiske arbejdsmarked. Disse temaer indebærer et stort potentiale for udveksling af både informationer og erfaringer om effektive kriminalitetsforebyggende indsatser og midler, hvor mulighederne for et styrket praktisk samarbejde mellem relevante nordiske myndigheder kan overvejes.

\section{Videreudvikling af arbejdsmiljøstra-} tegier- og tilsyn. Der vil være fokus på udveksling af erfaringer og viden om effektive arbejdsmiljøstrategier og tilsynsmetoder, herunder EU's arbejdsmiljøstrategi og andre relevante prioriteringer. En vigtig del af arbejdet vil bestå $i$ at opnå en mere konkret og anvendelig forskningsbaseret viden om, hvilke arbejdsmiljøstrategier og tilsynsformer der har en positiv effekt og fører til resultater ude i virksomhederne.

\section{INDSATSOMRÅDE 3}

Sikre en god balance mellem arbejdstagerbeskyttelse og fleksibilitet samt værne om den nordiske trepartsbaserede arbejdsmarkedsmodel.

Arbejdsmiljø- og arbejdsretsområdet er tæt forbundne, og det er derfor vigtigt 


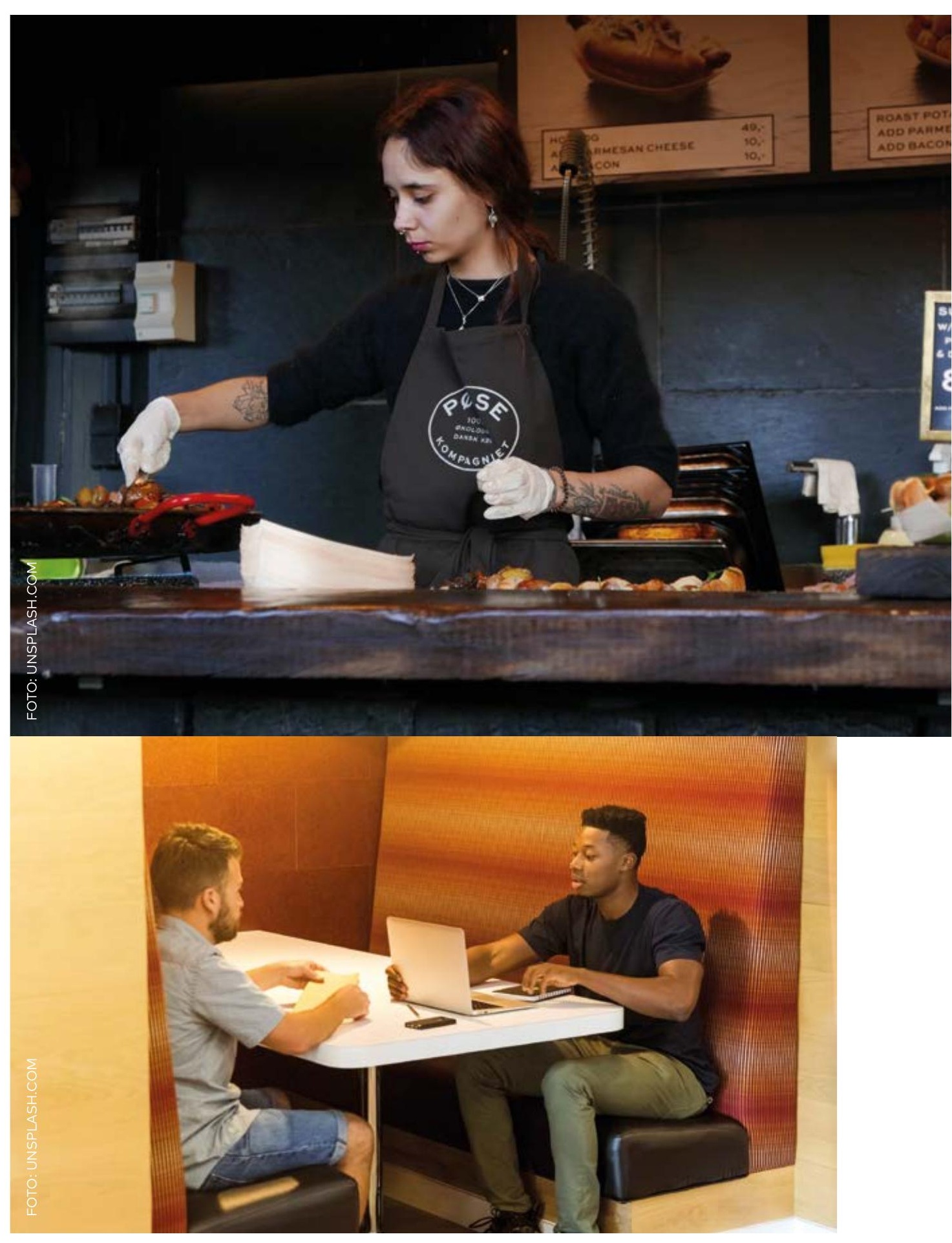


at anskue målene under indsatsområde 2 og 3 sammen. Nogle af de vigtige mål for at forbedre arbejdsretsområdet er at:

\section{Sikre balance mellem arbejdstagerbe-} skyttelse og fleksibilitet $i$ arbejdslivet. Fremtidens arbejdsliv byder på nye arbejdsformer og nye arbejdsopgaver. Disse nye måder at organisere arbejdslivet på vil få konsekvenser for de arbejdsretslige ansættelsesformer og relationer, hvorfor det bliver vigtigt at sikre, at det ikke får negative konsekvenser for den enkelte, for virksomhederne eller for samfundsøkonomien. Der prioriteres et fornyet fokus på, hvordan man kan skabe og videreudvikle modeller for, og sikre balance mellem, arbejdstagerbeskyttelse og fleksibilitet i arbejdslivet.

\section{Sikre ordnede forhold på arbejds-}

markedet. Der vil blive fokuseret på at opretholde og videreudvikle et seriøst arbejdsliv i Norden og samarbejde med arbejdsmarkedets parter om at forebygge og bekæmpe diskriminering, social dumping/arbejdskriminalitet og grå økonomi.

\section{Tilpasse og udvikle den nordiske arbejds-} markedsmodel. Den trepartsbaserede arbejdsmarkedsmodel er central i de nordiske lande. Det er en prioritet at klarlægge, hvordan man inden for det nordiske samarbejde gennem videnudveksling og samarbejde, blandt andet $i$ kontakten med EU og andre relevante internationale fora, kan værne om og videreudvikle den nordiske arbejdsmarkedsmodel og samtidig imødegå de udfordringer, som modellen står overfor. Det ønskes desuden at sikre modellens konkurrenceevne og bæredygtighed $i$ forhold til kommende arbejdsformer. Organisationsgraden og arbejdsmarkedets parters position og styrke på det nordiske arbejdsmarked er vigtige faktorer i denne sammenhæng.

\section{INDSATSOMRÅDE 4}

Styrke integration, lige muligheder og mobilitet på det nordiske arbejdsmarked.

Nogle af de vigtige tværgående mål på dette område er at:

\section{Fremme integrationen af nyankomne} og indvandrere. I samarbejdsprogramperioden vil der blive rettet særlig opmærksomhed mod initiativer, som skal styrke etableringen på arbejdsmarkedet, da beskæftigelse er et af de vigtigste elementer for at sikre en vellykket integration, og en vigtig komponent i forhold til at sikre bæredygtighed i velfærds- 
systemerne. Der er behov for at sikre hurtige, effektive og fleksible veje ind $i$ arbejdslivet. Nyankomnes deltagelse i indsatser, som giver dem forudsætninger for at etablere sig på arbejdsmarkedet og i samfundet, dialog med arbejdsmarkedets parter og frivillige organisationer samt partnerskaber mellem den offentlige og den private sektor, er vigtige elementer $\mathrm{i}$ en effektiv integrationspolitik. Et andet vigtigt aspekt i forhold til at fremme børn og unges integration $i$ samfundet er, at begge forældre deltager $\mathrm{i}$ arbejdslivet.

\section{Fremme ligebehandling og ligestilling $\mathbf{i}$} arbejdslivet. Samarbejdet på arbejdslivsområdet vil sætte fokus på at fremme ligebehandling med hensyn til køn, etnicitet, funktionshindringer etc. samt at forhindre segregerede arbejdsmarkeder. Her er balancen mellem arbejdsliv og privatliv en central faktor. I denne sammenhæng er det også vigtigt at gøre det nemmere for indvandrerkvinder at komme ind på arbejdsmarkedet og at sætte fokus på tiltag, som gør det enklere at kombinere arbejde, uddannelse og familie. Samarbejdet på arbejdslivsområdet vil desuden fokusere på at modarbejde diskriminering på grund af alder, køn, etnicitet, nationalitet etc.
Sikre mobilitet samt mindske og forhindre nye grænsehindringer i Norden. Det frie nordiske arbejdsmarked har været velfungerende i over 60 år, og det er vigtigt at opretholde og videreudvikle det $\mathrm{i}$ fremtiden. Arbejdet på dette område vil fokusere på hele tiden at forbedre mobiliteten på det nordiske arbejdsmarked ved at modvirke grænsehindringer og forhindre, at der opstår nye. Dette arbejde vil foregå under hensyntagen til EU og de rammer, som EU opstiller. Det er vigtigt at kaste lys over mobilitetens betydning, især i forhold til tyndtbefolkede områder og de udfordringer, man ser her, blandt andet den manglende balance, hvad angår kompetencebehov. 


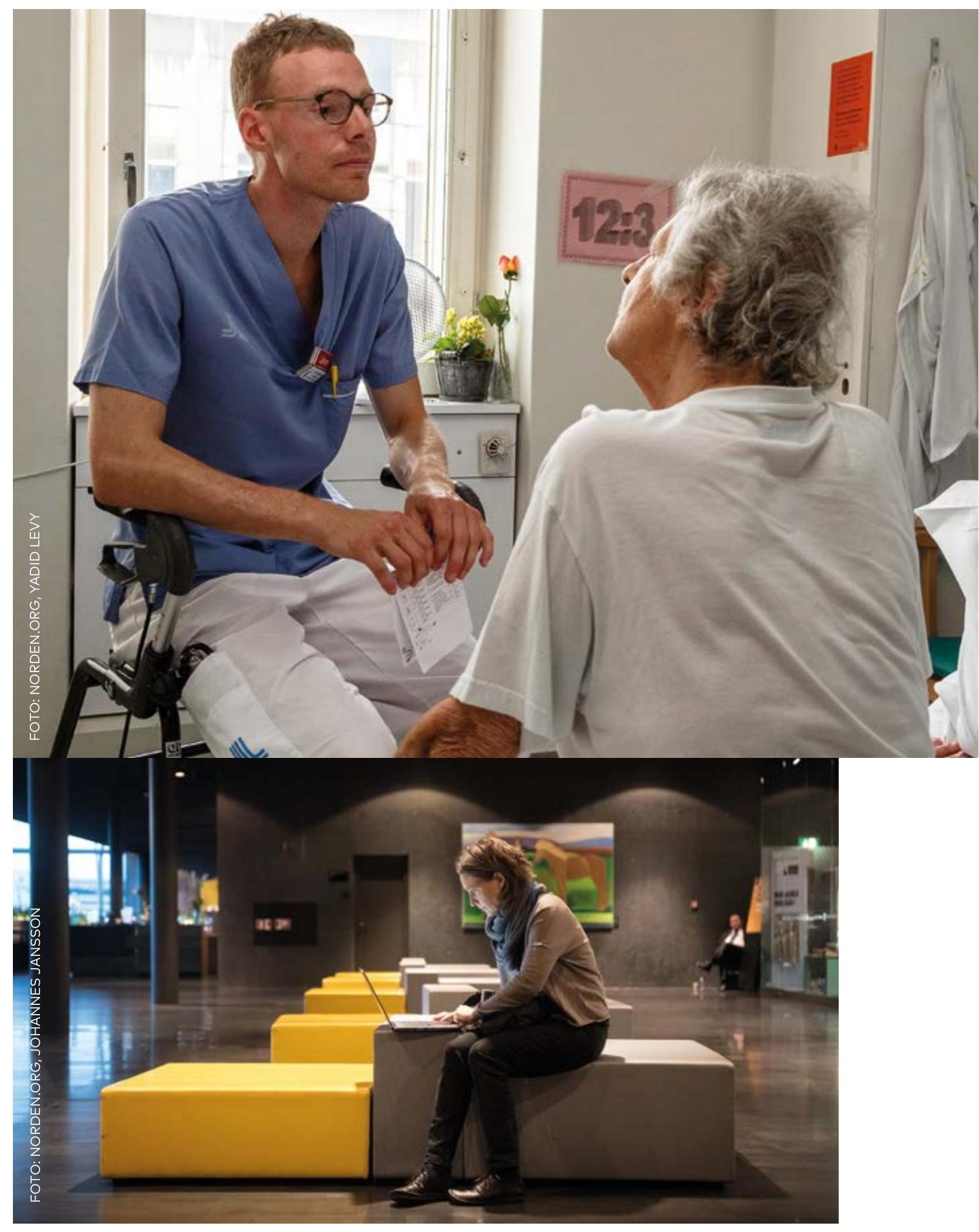




\section{Samarbejde om EU og andre internationale aktører}

Sektoren vil kontinuerligt arbejde på at styrke samarbejdet med EU og opmærksomheden på kommende forslag fra Europa-Kommissionen. EU-anliggender af interesse for Norden som helhed vil løbende blive taget op og drøftet på møder i ministerrådet, embedsmandskomitéen og udvalgene. Et vigtigt aspekt af dette arbejde er at minimere grænsehindringer og forhindre, at der opstår nye.

Især Arbejdsretsudvalget koncentrerer sig om EU-anliggender og har fokus på både den tidlige lovgivningsfase, igangværende forhandlinger, gennemførelsen af EU-lovgivning og afgørelser fra EU-domstolen samt andre lignende sager. Derudover har EK-A bedt den nordiske socialforsikringsgruppe om at følge udviklingen på ovennævnte områder for at forhindre, at der opstår nye grænsehindringer.

Den nordisk-baltisk-polske EU-informationsgruppe følger EU's arbejde med arbejdslivspolitik.

Ud over EU er der en række andre vigtige internationale aktører, som har betydning for det nordiske arbejdslivssam- arbejde. Den internationale arbejdsorganisation (ILO) er FN's fagorganisation for beskæftigelses- og arbejdsmiljøanliggender. I den indledende fase af arbejdslivssektorens samarbejdsprogram vil det blandt andet være vigtigt at følge og påvirke arbejdet med Future of Work, som er en del af ILO's 100-årsjubilæum i 2019. Dette jubilæum giver de nordiske lande samt Færøerne, Grønland og Åland mulighed for at bidrage med fælles nordiske synspunkter og god praksis, hvad angår fremtidens arbejdsliv, ligesom det vil udgøre fundamentet for det fortsatte samarbejde.

Organisationen for Økonomisk Samarbejde og Udvikling (OECD) har stort fokus på tiltag, som skaber vækst og beskæftigelse. OECD's faglige viden og analyser af arbejdsmarkedsrelaterede anliggender kan fungere som et supplerende bidrag til det nordiske samarbejde på arbejdslivsområdet.

I relevante sammenhænge vil repræsentanter fra blandt andet EU, OECD og ILO blive inviteret til at deltage i møder, på konferencer m.m. 


\section{Organisation på området}

Nordisk Ministerråd for Arbejdsliv (MR-A) har det overordnede ansvar for det nordiske samarbejde på arbejdslivsområdet og vil for de nordiske ministre med ansvar for beskæftigelse, arbejdsret og arbejdsmiljø udgøre et vigtigt forum for debat og erfaringsudveksling om, hvordan man bedst imødegår de fælles udfordringer på arbejdslivsområdet.

Samarbejdet organiseres af Nordisk Embedsmandskomité for Arbejdsliv (EK-A), som opstiller retningslinjer for og fordeler MR-A's budget. En fleksibel organisationsstruktur er helt central for, at det nordiske samarbejde på arbejdslivsområdet kan igangsætte og følge op på aktuelle sager. EK-A har nedsat tre faste udvalg - Arbejdsmarkedsudvalget, Arbejdsmiljøudvalget og Arbejdsretsudvalget - og nedsætter ad hoc-grupper efter behov. Ud over udvalgene er der også den nordisk-baltisk-polske EUinformationsgruppe, som hovedsageligt følger EU's arbejde med arbejdsmarkedspolitik, arbejdsrelateret lovgivning og arbejdsmiljø.

Udvalgene og arbejdsgrupperne spiller en vigtig rolle for viden- og erfarings- udvekslingen mellem landene på de respektive ansvarsområder. Derudover skal de bidrage med input til MR-A og EK-A.

Nordisk Institution for Videreuddannelse inden for Arbejdsmiljøområdet (NIVA) i Helsingfors er også en del af det nordiske samarbejde på arbejdslivsområdet, jf. side 20. Derudover medfinansierer MR-A Nordjobb-programmet, som er et mobilitets-og udviklingsprogram for unge nordboer, der ønsker at arbejde i et andet nordisk land (www.nordjobb.net). MR-A finansierer også et informationsprogram om det nordiske arbejdslivsområde på skandinavisk og engelsk (www.arbejdslivinorden.org).

Derudover skaber det formelle samarbejde vigtige netværk mellem nordiske myndighedspersoner på arbejdslivsområdet, som landene kan have stor nytte af i konkrete situationer. Det skal påpeges, at der ved siden af det formelle nordiske samarbejde internt i Nordisk Ministerråd også eksisterer et omfattende uformelt nordisk samarbejde, som i mange tilfælde går mange år tilbage. 

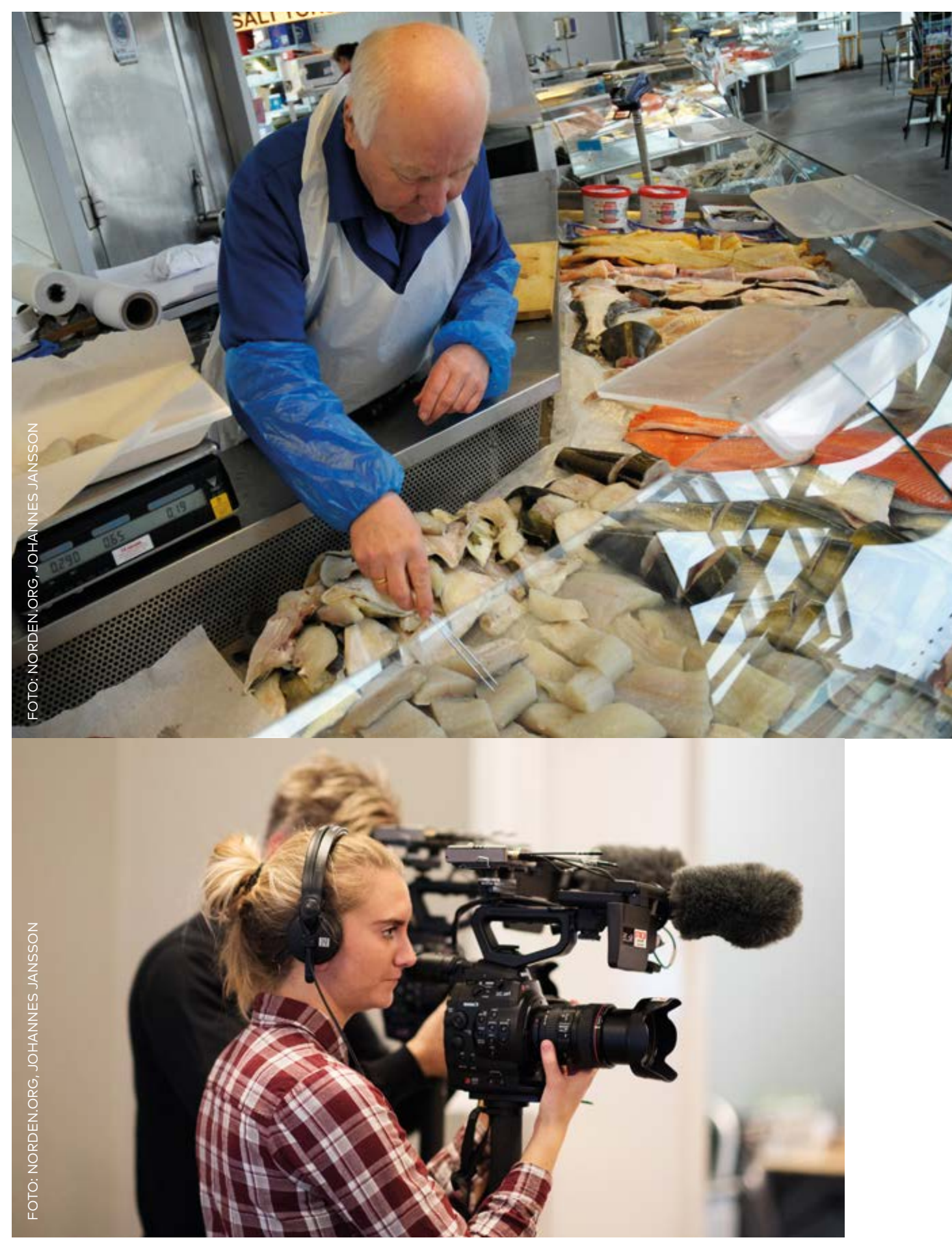


\section{Arbejdslivsområdets institution for videreuddannelse inden for arbejdsmiljøområdet - NIVA}

Nordisk Institution for Videreuddannelse inden for Arbejdsmiljøområdet (NIVA) er en nordisk institution inden for det nordiske arbejdslivssamarbejde under Nordisk Ministerråd (www.niva.org). NIVA's arbejde tager udgangspunkt i et strategisk mandat, som fastsættes af EK-A.

NIVA's primære opgave er at fungere som forum for udbredelse af viden om arbejdssundhed og arbejdsmiljø. NIVA skal skabe dialog om vigtige nyskabende arbejdsmiljøanliggender, som bidrager til et bedre arbejdsliv i Norden. Derudover skal NIVA skabe nordisk merværdi ved at arrangere symposier, workshops og seminarer på et højt akademisk niveau - især på områder, hvor der mangler tilstrækkelig kritisk masse i et enkelt land.

Arbejdssundheds- og arbejdsmiljøområdet er et tværfagligt område, hvor udfordringerne forandres i takt med et forandret arbejdsliv. De kommende års særlige udfordringer skal afspejles i NIVA's aktiviteter i perioden frem til 2021 og gælder blandt andet: Den aldrende arbejdsdygtige befolkning, psykosociale risici i arbejdslivet, udviklingen af ny teknologi, effektiv forebyggelse af ulykker i arbejdslivet, fremtidige arbejdsformer og deres indvirkning på arbejdsforholdene. 


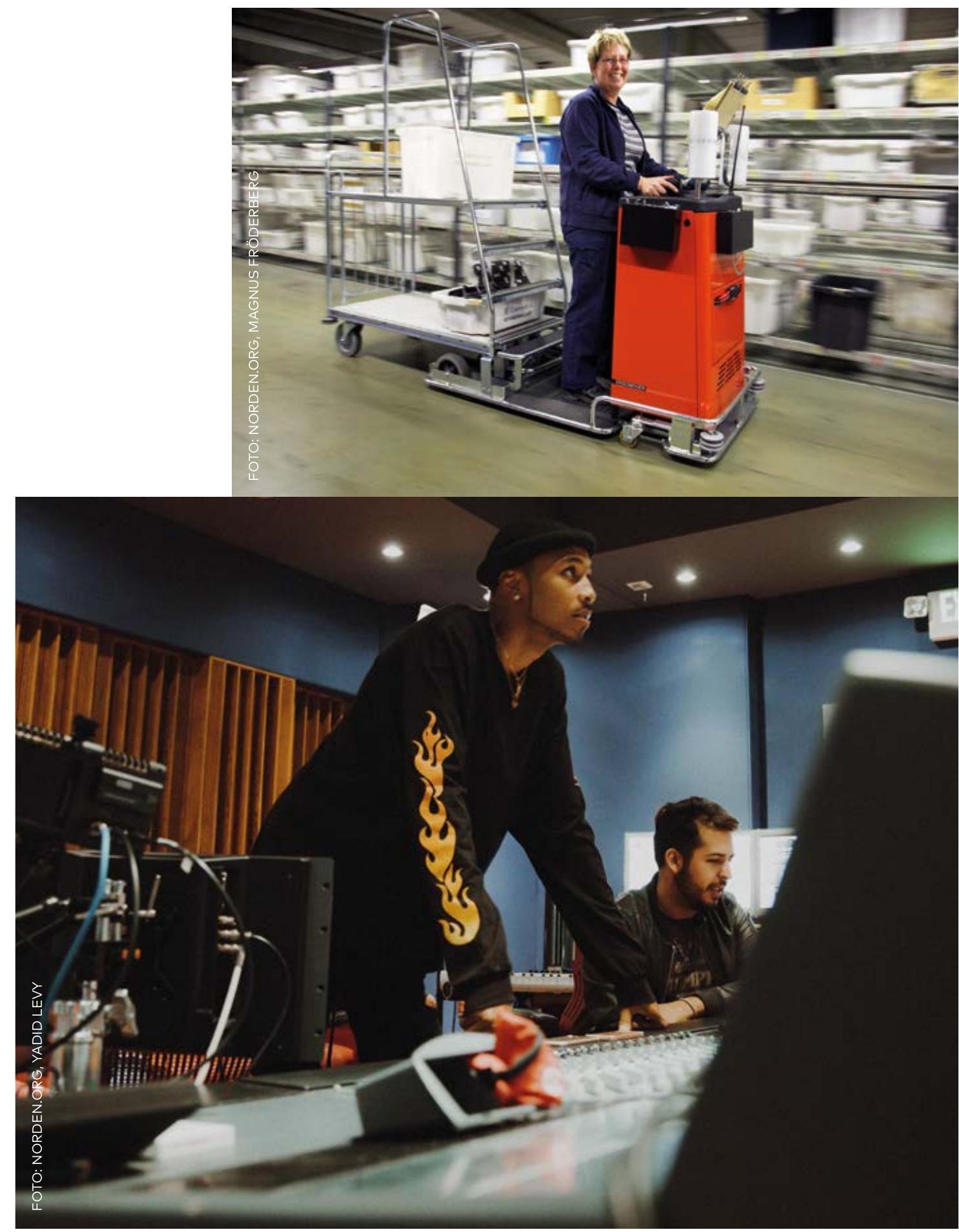




\section{Gennemførelse af samarbejdsprogrammet}

De udfordringer og indsatsområder, der nævnes i dette samarbejdsprogram, vil være centrale for det nordiske samarbejde på arbejdslivsområdet 2018-2021.

Samarbejdsprogrammet afspejles i budgettet for MR-A og kommer til at styre og definere forudsætningerne for de tre udvalgs arbejde og for resten af området.

I sektoren lægges der særlig vægt på, at der opretholdes en fælles, løbende og tæt dialog og informationsudveksling, som bidrager til at generere ny viden og nye initiativer. Dialogen skal foregå mellem en række aktører såsom arbejdsmarkedets parter, forskningsmiljøer samt relevante aktører og myndigheder. Samarbejdet kan tjene som inspiration til udvikling af national politik inden for de nationale rammer, men kan også udgøre et fundament for koordinering af synspunkter, i det omfang de vurderes at være relevante og gavnlige.

Samarbejdsprogrammet vil blive konkretiseret og implementeret, især i forbindelse med formandsaktiviteter og i udvalgenes virksomhedsplaner. De faste udvalg råder over begrænsede projektmidler, som de primært anvender til at forbedre det videnmæssige grundlag for erfaringsudveksling. Det gør de blandt andet ved at kortlægge og analysere ligheder og forskelle mellem de nordiske landes tiltag samt effekterne af disse. Projekterne vil bidrage til gennemførelsen af samarbejdsprogrammet.

Der vil også blive afholdt flere nordiske konferencer om aktuelle temaer på arbejdslivsområdet. Konferencerne danner grundlag for udveksling af viden og erfaringer, skaber mødesteder og fremmer netværk og udviklingsarbejde.

Dialogen vil i høj grad foregå mellem MR-A, EK-A, aktuelle udvalg og Nordisk Ministerråds sekretariat samt arbejdsmarkedets parter. Parterne inviteres til at komme med input til samarbejdsprogrammet og vil som regel også blive inviteret til trepartdiskussioner om aktuelle arbejdslivstemaer i forbindelse med de årlige møder i MR-A. Andre aktører samt råd og udvalg vil løbende blive inviteret, når det er relevant.

Derudover forventes sektoren at deltage i tværsektorielle initiativer, som initieres af for eksempel statsministrene, MR-SAM eller Nordisk Råd. Samarbejdsprogrammet vil i alt sit arbejde integrere Nordisk Ministerråds strategi for bæredygtig udvikling og, i den udstrækning det er relevant, inkludere perspektiverne 


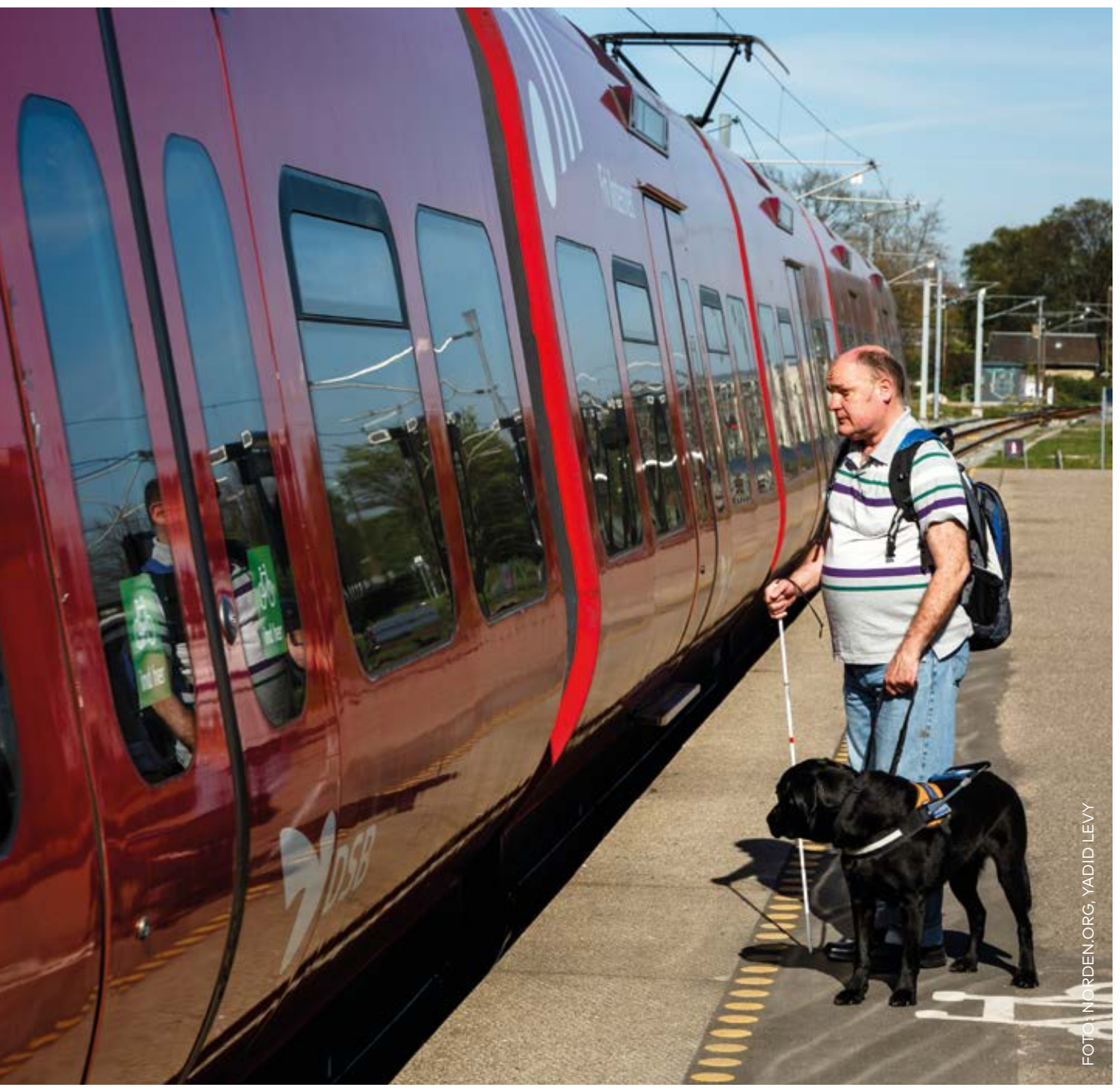

ligestilling, børn og unge, integration og funktionshindringer som nævnt på side 6. Arbejdslivsområdet samarbejder også med andre sektorer i Nordisk Ministerråd, især Nordisk Ministerråd for Social- og Helsepolitik (MR-S), Nordisk Ministerråd for Bæredygtig Vækst
(MR-Vækst) og Nordisk Ministerråd for Ligestilling (MR-JÄM). Inden dette samarbejdsprogram i 2021 ophører med at gælde, vil der blive foretaget en opfølgning af erfaringerne fra programmet. 


\section{$\mathbb{1}$}

\section{Nordisk Ministerråd}

Nordens Hus

Ved Stranden 18

1061 København K

www.norden.org

Det fælles arbejdsmarked er en af hjørnestenene i det nordiske samarbejde. En stor og kompetent arbejdsstyrke er vores vigtigste ressource, og den danner grundlaget for et konkurrencedygtigt nordisk arbejdsmarked og for udviklingen af de nordiske velfærdssamfund.

Samtidig står de nordiske arbejdsmarkeder over for betydelige forandringer som følge af blandt andet den demografiske udvikling, øget globalisering, teknologisk udvikling og international konkurrence.

Samarbejdsprogrammet for arbejdsliv 2018-2021 peger på en række af disse væsentlige udfordringer på arbejdslivsområdet og beskriver, hvordan det nordiske samarbejde kan bidrage til at løse dem. 